\title{
The Impact of Religion, Science, Economy and Politics on Seljuq Dynasty Metalworking
}

\author{
Raheleh ErfanManesh ${ }^{1}$, Lahya HosseiniKermani ${ }^{1}$, Ali Piri ${ }^{1} \&$ Maryam ForoughiNiya ${ }^{1}$ \\ ${ }^{1}$ Instructor Professor in College of Art and Architecture,University ofSistan and Baluchestan, Iran \\ Correspondence: Raheleh ErfanManesh, Instructor Professor in College of Art and Architecture,University \\ ofSistan and Baluchestan, Iran. E-mail: Rahele_erfan@yahoo.com/Hoseyni.lahya@yahoo.com/ \\ Piri_ali@yahoo.com/m.foroughinia@gmail.com
}

Received: March 2, 2016

doi:10.5539/mas.v10n6p67
Accepted: March 14, 2016

Online Published: April 10, 2016

URL: http://dx.doi.org/10.5539/mas.v10n6p67

\begin{abstract}
We have experienced significant development in art, industry and science through rise of Seljuq dynast. It has smoothed its way in the field of governing over people based on relying on religion. Also, it has attempted to connect its blood to Iranian myths. The presence of all Kufic scripts, fights, and kings battles and female harp player in the metal dishes can demonstrate the impact of politics and religion on the art marvelously. Astrology has impacted Khorasan School and Seljuq dynasty's metalworking and ethereal designs have been included one of the decorative designs in art of this era. The new metal combinations which have been invented by Muslims have an important effect on metalworking industry. In addition to science development, the economic condition of the society has helped to the affluence of metalworking specially inlaying metalworking in this era. The questions which are considered in this study include: has accepting Islam religion by Seljuq dynasty affected Khorasan School metalworking? What has been the effect of sciences like chemistry, alchemy and astrology on metalwork of this era? How much Seljuq dynasty has been impacted by pre-Islamic art? For achieving proper answers, the method of research is descriptive-analysis and information has been chosen by library research method. The purpose of this study demonstrates the close connection between rational, religious, politics and art sciences.
\end{abstract}

Keywords: Seljuq Dynasty, metalworking art, science, religion, politics

\section{Introduction}

Recognizing the features of Seljuq art and typical samples have changed gradually the metalworking art based on form and also decorations after passing four centuries of Muslims' invasion over Iran. Therefore, the metalworking art has been developed in Khorasan obviously and found its special features and created Khorasan especial metalworking school. This school has flourished in Seljuq dynasty and Seljuq Turks after immigration from Turkestan have come to Transoxiana at the beginning of fifth decade (1037) and then settled there and accepted Islam religion. This dynasty could conquer present Khorasan, Baghdad, and the north of Iraq, Suria, Armenia and finally Anatoly (Lakpour, 1996:12). The development of different arts have been considered and supported by Seliuq kings and monarchs and also, the metalworking has had significant progress at this era. The five cities like Khorasan, Nishapur, Merv, Herat and Balkh have been recognized as the center of metal works. Khorasan metalworking school has continued up to Moghul's invasion to this center. Seljuq's dynasty metal works have demonstrated changes and evolutions of metalworking art in Sassanid era and after it and they represented especial features of Khorasan School. Also, features of its metalworking can be stated as follows:

- Some innovations and diversities have been created in Khorasan School through protecting pre traditions of metalworking in making objects. They can be seen in the shape of remained flagons, bowls and oil lamps of this era.

- $\quad$ The replacement of small and dense designs by usual single designs in Sassanid era.

- Settling of ivies and scripts divisions in bracelet designs which have been allocated to Khorasan metalwork metalworking.

- In Islamic era, the script in metalworking art especially in Khorasan has an especial position and almost metal dishes have been endowed with prayers and good wishes for their owners.

- Another feature of Khorasan School has been showing man in various positions such as playing 
musical instruments and dancing.

- $\quad$ Rabbits with two ears longer than usual

- Small birds: these birds' designs have been seen in the Nishapur clays.

- $\quad$ Braids of three to four strands

- $\quad$ Ivies and wine leaves which are as one of main rows of design or decoration for background of other designs (Lakpor,1996: 13)

- In Seljuq dynasty, especially in Khorasan school, metalworking inlaying have been considered and artists of metalworking have applied golden, silver and copper wires for inlaying bronze or brass dishes.

Khorasan School in the field of Iran's historical, cultural, art and scientific revolutions has been considered as significant and substantial eras of Islamic civilization. It has been considered not only as golden age of industry and technique progress, but also it has achieved many developments in art and cultural fields. Seljuq art in this school has presented the close relation of rational science and art. It is necessary to mention this point that Seljuq people have had Sunni Islam and have intensively been devoted for the kingdom. They have considered Quran and tradition as their life basis and then Arabic language and script have propagated at that time for government, society and art in Iran. The holy Quran verses, prophet traditions and more than others, recitations, prayers, recommendation and piece of advice have been seen in the metalworking art of Khorasan School. In addition to religion effect, sciences developments have affected its metalworking and decorations have been experienced as alloy or moulage at the surface of the dish. Khorasan metal workers have completed the inlaying works of bronze objects with other metals such as copper and silver. Inlaying work at the east of Iran has been valued and initiative method of Herat, Nishapour, Sistan and Merv where have been Iran center for metalworking, gradually has reached to all Middle East and imitated. Although the engraving has been propagated, inlaying and marquetry have become the most significant factors for decoration. Some of bronze dishes have been inlayed or marquetry with copper as Iran's tradition and some of them has inlayed with copper and silver or just with silver. This fact has shown the effect of science in this era's art.

Science, economy, religion and politics are the options which have affected greatly Khorasan School and this essay attempts to study these factors on metalworking art.

\section{Literature Review}

Mohammad Afrough and Alireza Norouzi Talab in their essay have studied astrology and analyzed one sample of Seljuq metalwork based on science "Analyzing Astrological Concepts as Decorative Shape and Figure of Seljuq Metal Works. Case Study: Brass Basin". Alireza Rafiee and Aliasghar Shirazi in their essay "Seljuq Dynasty Art" have mentioned the relation between mathematics and Seljuq's miniature art, glassworks, architecture, brickwork and metalworking. Nasrin Hashemi Rashidabadi and Ahmad Salehi Kakhaki in "The Study of Materials, Articles and Techniques for Making Seljuq Metal Censer Burner in Khorasan" have analyzed the material, articles and techniques of Seljuq censer burners. Taghi Azad Armaki and Maryam Kamali in "Politics Legitimation and Power Structure in Seljuq Dynasty" have studied the relation of society structure and politics in Seljuq era. Alireza Nourozi Talab and Mohammad Afrough in "Studying Form, Decoration and Contents of Seljuq and Safavid Metalworking Art" have studied and analyzed some works of internal and external museums based on cultural and art significant indicators in two Seljuq and Safavid dynasties and also their differences and similarities. But none of these essays have studies the politic effect, society conditions in Seljuq dynasty and their effect on metalworking.

\section{The Effect of Science and Economy on Seljuq Metalworking}

Through the emergence of Seljuq dynasty at the east of Iran about 1027, a brilliant period of Islamic metalworking has been started. Different sciences have applied many effects on metalworking in this era such as chemistry, industries and arts related to it. The casting industry which is one of chemistry and material branches, has flourished in this era and bronze objects have been popular with embossed decorations such as a mirror and animal figures and tablets in Khorasan and Iraq at Seljuq dynasty. For example, a zebu which is feeding its calf can be mentioned (Figure 1). 


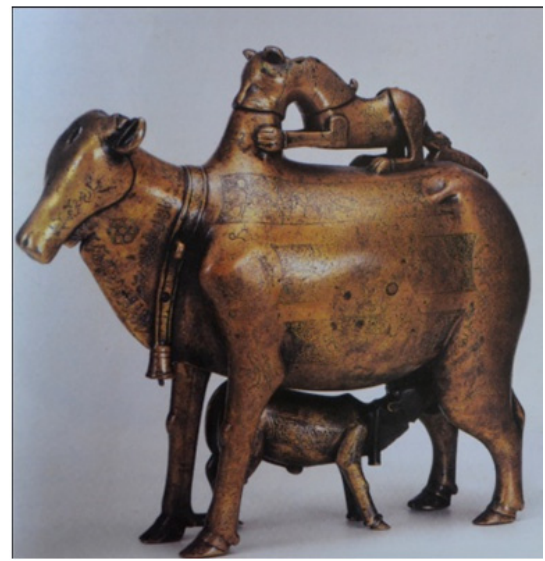

Figure 1. A flagon like a zebu, 1206, probably Khorasan, Hermitage Museum

(Vared, 2005:32)

As it has been said, chemistry and material science is one of sciences that have affected Seljuq dynasty's metalworking. "Oxides and new metal compositions which have been discovered at fourth and fifth centuries by Muslims" (Norouzi Talab, 2011: 126) have many significant effects on metalwork industry. Using metals and applied alloys have been common such as copper, silver, gold, bronze (copper and tin) and brass (copper and zinc). Metal workers of Khorasan School have completed the inlaying industry of bronze objects with other metals such as copper and silver. This industry has begun in the east of Iran in Khorasan and spread and propagated to other areas of Iran and Iraq. Also in the east inlaid working has achieved art value and initiative methods of Herat and Nishapur, Sistan and Merv have been centers for metalworking and gradually reached to Middle East and imitated. "In thirteenth century, Mosul in the north of Iraq has been one of the big centers for Islamic inlaying and actually, the fame and popularity of this city have developed as much that for a long time all copper and silver inlaying works have been referred to this city" (Dimand, 2004: 137). A sample of this inlaid works can be seen in Bobrinsky Jug (picture 2):

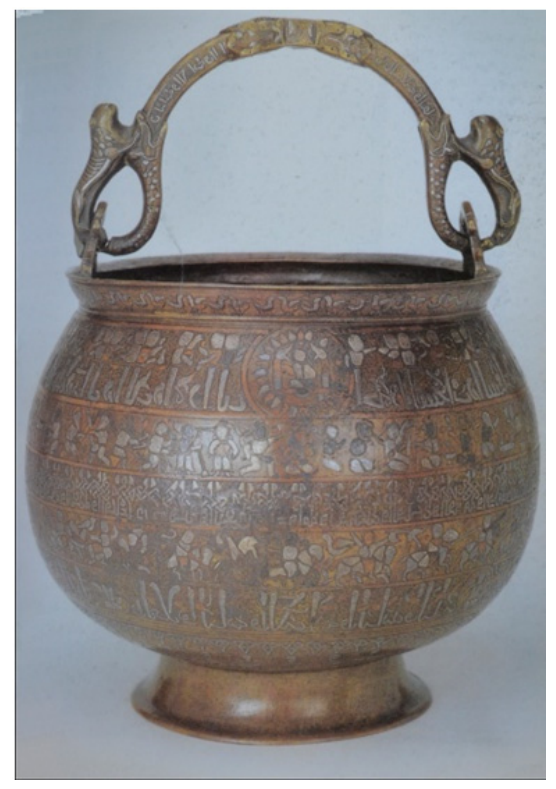

Figure 2. Bobrinsky Jug, silvered and coppered bronze, Made in Herat in 1163, Hermitage Museum, Leningrad (Ferrier, 1954:175)

Also, astrology has had impact on Khorasan School significantly. These influences in the field of metalworking have been obvious and ethereal figures have been the main decoration figures in art of this era. The sample of 
metalworking of this era has been a mirror in the Count Wallerstein collection with astrological signs (Figure3). Although Islamic art can be introduced as cosmic art, this art has been applied more in Khorasan School than the other eras. Islamic great astrologists such as al-Biruni, Omar Khayyam, Abu Sahhl al-Quhi and Abu al-Mozafar Asfazazi who have lived between fourth and seventh centuries have been the important reason of progressive attention to astrological matters. Another prominent work which has mentioned to astrology development in this era is making astrolabe.

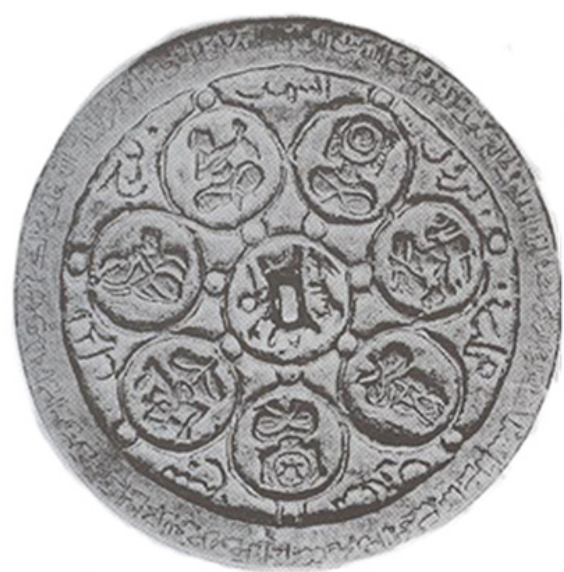

Figure 3. A mirror, bronze with embossed figure, 1153, Harary Collection, 17CM diameter, (Pop and Ackerman, 2008:1301)

In addition to sciences which have been stated in this era, the wood carving, mosaic, vitreous enamel, etching, embossed and hammered works have been propagated. Iranian metalworkers have applied wood carving professionally in decorating and making metal dishes in Khorasan school and made the candlestick and incense burner as animal and birds figures. In Metropolitan museum, an incense burner is existed in the lion figure which has been made by Khorasan school method and its shoulder, neck and leg is decorated by various figures (Ferrier, 1954: 171) (Figure4).

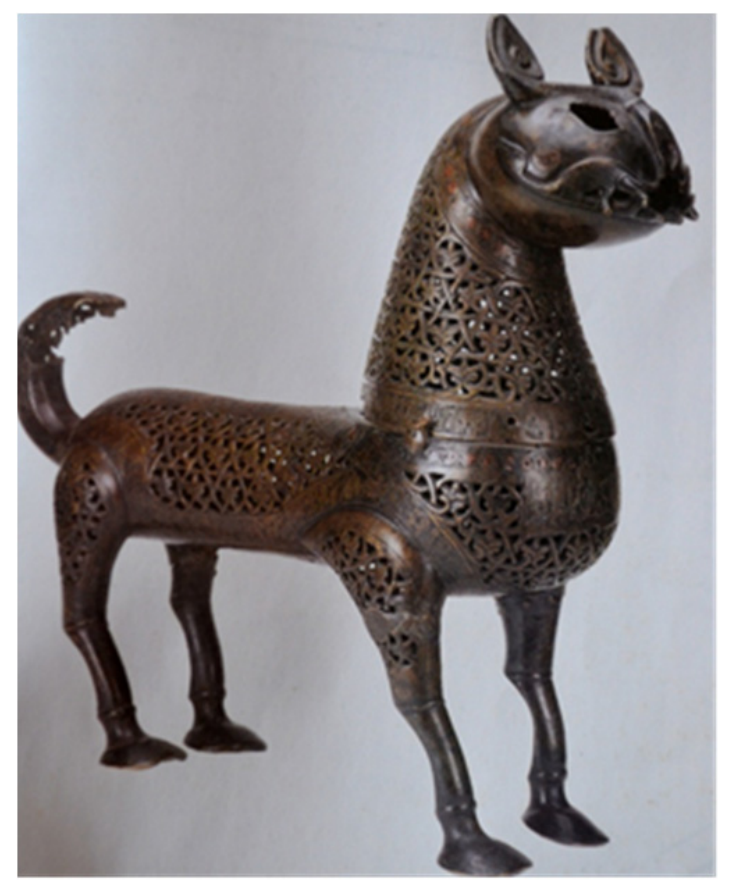

Figure 4. An incense burner, bronze, inlaid by copper, carving work, Hermitage Museum, 47CM length, Hijri $6^{\text {th }}$ decade (Ferieh, 1954:172) 
Islamic decorative arts in Khorasan School, especially at the end of sixth century and beginning of seventh century have been reached to extreme innovation, invention and luminosity. At this era, even usual and valueless objects which have been produced for ordinary people have had high quality. Based on economic situation and that era condition, the metal has many usages among people. Cooking has been performed in copper pots, although in some places stone pots have also been used. Ingredients especially spice and vegetable have been mashed in a bronze pounder (Figure 5). Tools and instruments in the entrance door such as a knocker, shaft, tent-nails, bolt and ramp have been made by iron. The purpose of stating these details is that to mention the middle class of society have had a better economic situation in this era and applies metal objects simple and unadorned in their daily life. But nobles and aristocrats especially kings and courtiers have used valuable metal dishes.

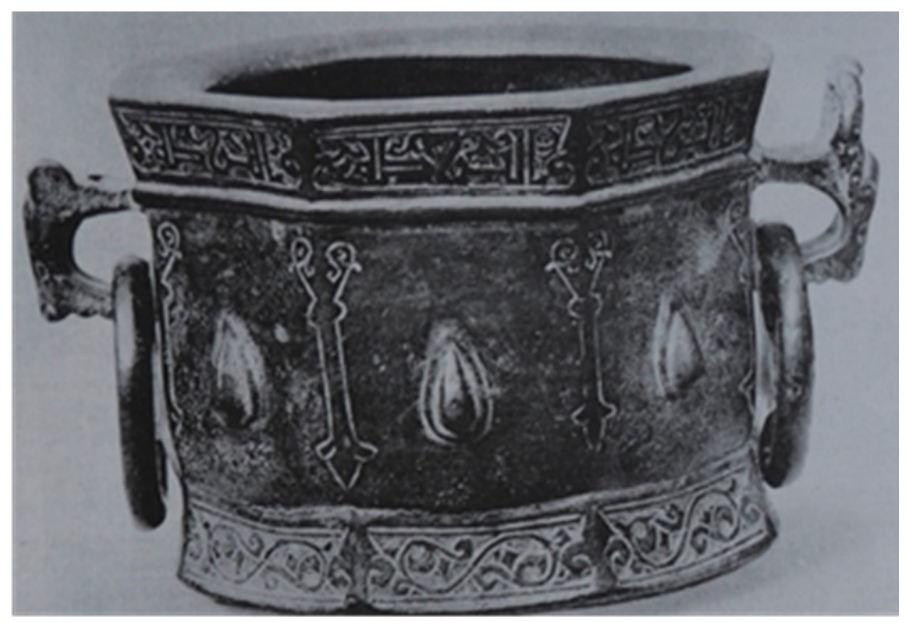

Figure 5. a pounder, carved bronze, $6^{\text {th }}$ or $7^{\text {th }}$ Hijri decade, Metropolitan, 14/61 CM height, (Pop and Ackerman, 2008:1280)

Bronze and brass have been the most popular metal that art historians have not discriminated them. Some of silver-gilt dishes and some designs with niello have been remained. Gold has just been protected in jewelries, but through evaluating the name of some people who have been mentioned in literary sources or on golden jewelries as goldsmith, it is understood that gold has had public and communal usage (Heidarabadian, Abassifard, 2004: 64-68).

\section{The Impact of Religion on Khorasan School Metalwork}

Turks' arrival to Iran has begun with Kara-Khanis Khanate and Ghaznavids and by Togrul and establishing Seljuq dynasty has reached to its height (Bartold, 1956:68; Ibn Howqal, 2004:510). Seljuq has accepted Islam before attacking to Middle East and Khorasan and included this rule "Muslims all are brothers". This fact has had a significant impact on its acceptance in these areas and the lack of people's resistance against Seljuq. Gradually, Seljuq has defeated its two rivals Ghasnavids and Byuid dynasties. It has conquered Nishapur and other Ghaznavid territories in Khorasan and in 1037 and then proceeded to Baghdad. Seljuq dominance through religion weapon has helped it to reach to monarchy from slavery and from Central Asia deserts has decided to conquer Iran and its obedience has not been costly by Iranians. Seljuq dynasty has guaranteed its government on extensive emperor for long time through accepting Islam and dividing government among important religious, administrative, court and military posts (Bayhaqi, 2012:926).

Seljuq dynasty has been one of the most prominent eras for Khorasan culture and science. In this era, many scientific and religious centers and institutions have been established and especially in Nishapur, an especial scientific and religious splendor has been formed. Different schools and religions of thought and belief have been flourished in Khorasan and achieved many followers. Almost residents of important cities such as Nishapur have been Shafii and the minority has been Shia and Hanafi. The position of different religions has had many impacts on Seljuq politic relations (Rohi, 2014:51). The metalwork in Khorasan school has the same dignity and glory that has been the superiorities of Sassanid metal and industrial works that has been adapted with Seljuq taste and nature although it has not been without accuracy, elegance and beauty appropriated with its Islamic aspects and tendency to revival Iranian rules and techniques. 
In Khorasan School, some bronze dishes have been achieved included silver and golden decoration and observers turn to their decoration richness and precise designs (Mohammad Hassan, 1957:25). The reason of decorating metal works with gold and silver has been this fact that Islam religion has made abominable and forbidden making dished by expensive metals such as gold and silver and therefore, Islamic craftsmen for avoiding these forbiddingness and prohibition have applied these two metals in their industry as gold and silver-gilt and exposed to enamored people of this sublime and worthwhile art (Ehsani, 19642:139). Islam has impacted artist's thought and the theosophical and spiritual condition which is existed in Islam, have been experience obviously in artists' works after Islam, artists have followed theosophical and Islamic thoughts freely in this era (Ayat Allahzadeh Shirazi, 1983:169).

Abbasid caliph has known his caliphate without politic and religious power because of the presence of Shia Buyid dynasty in Baghdad in that era and empowering of Egypt Fatimid caliphate over Islam; therefore he has attempted to revival his power as the leader of Islam caliphate through applying Sunni Seljuq sword power, maybe to find a way to return to his previous political power. The religion has presented its influences on propagation of Arabic script and diversity of Kufic scripts in decorating works. The contents of works in Seljuq dynasty have been in Arabic include a prayer for healthy, chance, much property, long-life, forgiveness and mercy for its owner (Azad Armaki, 2012: 138). For example, the Figure 5 can be mentioned to see Kufic script at the edge of the dish.

Iranian Muslims have step progressively through applying Kufic script. When Europeans have concerned on their art innovations on metal sculpturing, metalworkers of Khorasan School have thought about finding new codes for expressing their feeling and after searching they have found these codes in Islam. Iranian artists especially Seljuq artists have given the greatest degree of beauty of metalwork to Arabic scripts. Through applying Kufic script and the beauty of each letter and power and dignity of this script, they have created beautiful metal works presented art innovation that Iranians have been profited them extremely.

\section{Policy in Seljuq Dynasty}

Initially, Seljuq kings have attempted to legitimate their power through using Iranian fame and ancestry to pass a way to conquer Muslims' heart quickly. They have used Iranian's ancient myth related to Turan and revolutions have been reached to Sassanid and Islamic eras and considered themselves as Turanian kings' successors and from Afrasiab slip and called Al-Afrasiab (Juvayni, 2009:87-88; Sadr al-Dyn, 1933: 74).

Nezam al-Mulk at the beginning of Book of Government about Malek Shah Alp Arsalan has provided that:"The great God has created the kingdom world of two principals including kingdom and leadership in Iran family, ancestor by ancestor to Great Afrasiab and decorated them by the dignity and munificence that world territories have been free from them" (Ghazvini Razi, 1952:18). They have secured their connection with charismatic supremacy of Iranian's great mythology through making descent for themselves.

For this purpose, Khorasan school flagons, goblets and glasses have been decorated with animal and bird heads by imitating Sassanid art and maybe it has been so that pre-historic eras of Aryan tribes which have immigrated to this country have believed that dinking in dished which have made as powerful animals or their figures have been designed on the body of dish caused the transportation of animal power to human (Figure 1). In this Figure, a lion is jumping on caw back and shaped as a handle. This Figure is a reminder of metal flagons of Sassanid era which it is not possible to wonder and surprise because in Islamic age, Sassanid metal works traditions have been affirmed. But the figure of a lion attacked a hunch is so old and probably it has been a planetary signs before history. This figure has been a sign of dominant power in Achaemenid emperor or before it.

The other figure which has been continued or imitated from pre-Islamic arts which has been revealed in metal works is human figures. The human figure applied in metal works especially in Khorasan school and seen in different positions such as hunting, ceremonies, banquet, battle, riding that usually have been derived from pre-Islamic decorated figures especially from Sassanid (Tohidi, 2007: 54). In the hunting scenes, humans have been designed by more movements usually riding horse, with arrow and bow or sword and hunting animals. In the battle scenes, warriors in riding horse or walking position have been battling or with battle tools. First, this method of decoration has been for recording historical events, but in Islamic era has found a decorative position in ceremonies scenes, kings and courtiers have been shown sitting on a bed and servants around them in respecting position. In playing music scene, some musicians have been playing different musical instruments (Figure 6). Musical instruments including pipe and flute, tambour, lyra, daf (frame drum) and harp and decorating plans derived from ancient Iran art have been seen frequently that flourished by Islam emergence. 


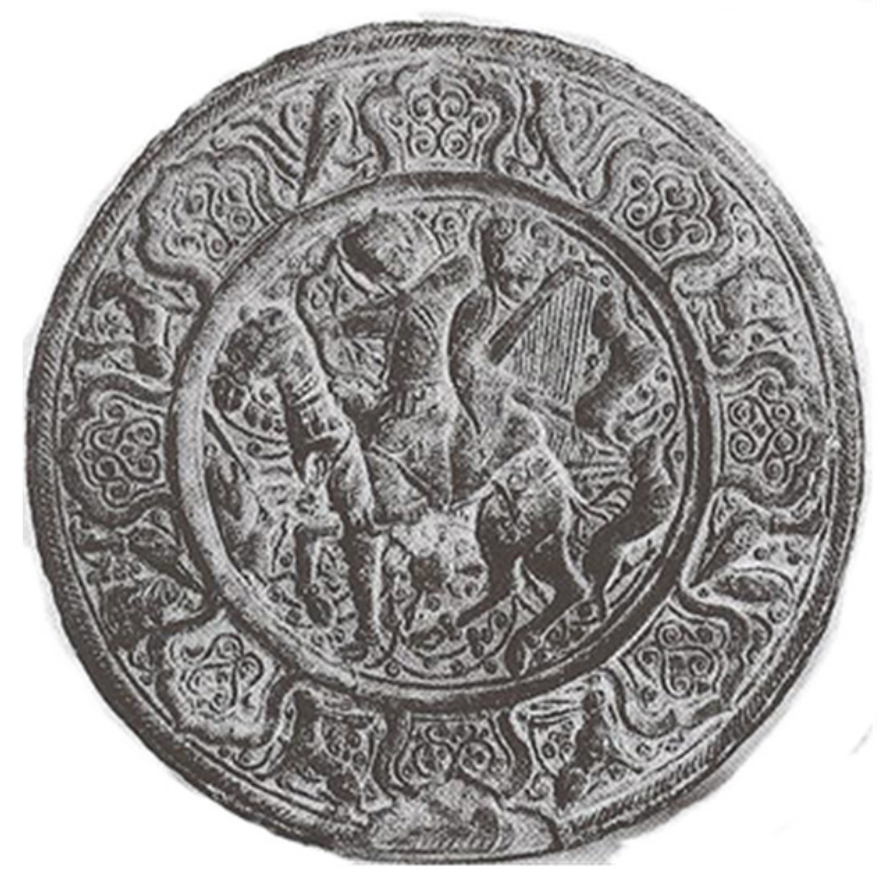

Figure 6 . a bronze wear plate, $12^{\text {th }}$ century, 18 Cmdiameter, belongs to Dimouti (Pop, 2001:117)

\section{Conclusions}

Khorasan school metal works, mostly have had human, animal and inscription decorations and the most techniques has been laying (with silver and gold), etching, silver-gilt and craving works and inscription texts have been prayers for its owner and moral recommendation. Through studying metal designs of this school, it is understood that these designs have been more various than previous works based on their widespread technique and varied designs. The structure of art in this era has presented the close relation between rational and art sciences. According to what has been stated, the science development and dominant economic situation in the society has caused all techniques have been propagated and this era has been considered as one of especial eras for metal works and also, accepting Islam by Turks and observing Sunni principals have propagated Kufic script among Seljuq's Turks. Turks who have known almost sciences propagated Kufic script and used all decorated Kufic scripts in their art. In this era, at the end of Kufic letters in metal works, has been decorated by diffused human and animal heads. Also, the impact of Sassanid art and culture has been obvious in metal works. Designing king which has been derived from pre Islam designs that presented Seljuq's kings have wanted to relate their ancestor to Iran's mythical and ancient past.

\section{References}

Afrugh, M., \& Nourozi, T. A. (2012). Studying Astrological Concepts as Decorated Figures and Forms of Seljuq Metalworking. Case Study: Brass Jug. Negareh Scientific-Research Journal, 21.

Ansaree, M., \& Hejazi, M. (2002). Aesthetical Study of Designs in Iran's Metalwork Art. Art Modaress Journal, 3.

Ayat, A. Z., \& Shirazi, B. (1983). Studying Metalworking in the Seljuq era. Art Journal, 3.

Azad, A. T., \& Kamali, M. (2012). Political Legislation and the Power Structure in Seljuq Dynasty. Historical Sociology Journal, 2.

Bartold, V. V. (1997). The History of Middle East's Turks. (Ghafar Hosseini). Tehran: Touss Publication.

Bayhaqi, \& Abul-Fadl, M. H. (2011). Bayhaqi History. (Introduction, Correction and Notes by Mohammad Jafar Yahaqi and Mehdi Seydi). Tehran: Sokhan Publication.

Dimand, M. (2004). Islamic Industries Guidance. (Abdu Allah Faryar). Tehran: Scientific and Cultural Publication.

Ehsani, M. T. (2011). Seven Years Metalwork Art in Iran. ( th $^{\text {th }}$ Edition). Tehran: Scientific and Cultural 
Publication

Ferrier, R.W. (1995). Iran Arts. (Parviz Marzban). Tehran: Pajuhesh Farzan Rouz Publication.

Ghazvini, R., Abdul, J. (2012). Al-Naghs. (Mir Jalal al-Dyn Mohadess). Tehran.

Hashemi, R., Abbadi, N., \& Salehi, K. Ahmad. (2012). Studying Material, Articles and Techniques for Making Seljuq Metal Incense Burners in Khorassan Area. Scientific-Research Journals of Islamic Art Studies, 17.

Hsseini, S. (1933). Akhabr al-Dolat Al-Seljuq. (Mohammad Iqbal Lahuri).

Ibn, H. M., \& Ibn, H. (2005). Almontazam Fi Tarikh and Omam. Beirut: Dar al-Katab Publication.

Juvayni, A. M., \& Ibn, M. (2009). Juvayni History. (Corrected by Mohammad Ghazvini). Tehran: Negah Publication.

Khazaee, M., \& Mosavi, H. Bahar. (2012). Language and Expression in Iran Metalwork Art. Ketab Honar Journal, 165.

Lakpour, S. (1996). White Zink. Tehran:Hozeh Honari Publication.

Nourozi, T. A., Afrough, M. (2010). Studying Form Decoration and Contents of Seljuq and Safavid Metalworking Art. Scientific-Research Journals of Islamic Art Studies, 12.

Pop, A. (2001). Iran Art Masterpieces. (Parvis Natel-Khanlary). Tehran: Scientific and Cultural Publication.

Pop, A., \& Ackerman, P. (2008). A Survey in Iran Art. (Edited by Sirous Parham). Tehran: Scientific and Cultural Publication.

Rafiee, A., \& Shirazi, A. (2007). Seljuq Art: The Union of Art and Science. Negareh Scientific-Research Journal, 5.

Rouhi, A. (2014). Religion in Seljuq Era's Khorassan. Iran Local Histories Research Journal, 2.

Tohidi, F. (2007). Basis of Metalworking, Miniature, Pottery Arts. Tehran: Samira Publication.

Varjavand, P. (2005). Maraghe Astrolabe Research. (2 ${ }^{\text {nd }}$ Edition). Tehran: Amirkabir Publication.

Zaki, M. H. (1987). Iran Industries History after Islam. (Mohammad Ali KHalili). Tehran: Eghbal Publication.

\section{Copyrights}

Copyright for this article is retained by the author(s), with first publication rights granted to the journal.

This is an open-access article distributed under the terms and conditions of the Creative Commons Attribution license (http://creativecommons.org/licenses/by/3.0/). 